\title{
Characterization of a thermostable polysaccharide bioflocculant produced by Virgibacillus species isolated from Algoa bay
}

\author{
Cosa Sekelwa*, Ugbenyen M. Anthony, Mabinya L. Vuyani and Okoh I. Anthony \\ Applied and Environmental Microbiology Research Group (AEMREG), Department of Biochemistry and Microbiology, \\ University of Fort Hare, Private Bag X1314, Alice 5700, South Africa.
}

Accepted 26 April, 2013

\begin{abstract}
We evaluated the bioflocculant production by Virgibacillus species isolated from a marine environment in the Eastern Cape Province of South Africa. Culture conditions for optimal production of the bioflocculant included: glucose as sole carbon source (flocculating activity $91.8 \%$ ); complex nitrogen source (urea + yeast extract $\left.+\left(\mathrm{NH}_{4}\right)_{2} \mathrm{SO}_{4}\right)$; inoculum size of $2 \%(\mathrm{v} / \mathrm{v}$ ); initial $\mathrm{pH} \mathrm{10}$; and calcium as mediating factor. Optimum dose of the purified bioflocculant for the clarification of $4 \mathrm{~g} / \mathrm{l} \mathrm{kaolin}$ clay suspension at neutral $\mathrm{pH}$ was $0.3 \mathrm{mg} / \mathrm{ml}$. Chemical analysis of the purified bioflocculant revealed it to be mainly composed of uronic acids $(87 \% \mathrm{w} / \mathrm{w})$. Scanning electron microscopic observations were indicative of a porous bioflocculant structure. Fourier transform infrared (FTIR) spectrum revealed the presence of carboxyl and hydroxyl groups whilst the themogravimetric analysis (TGA) showed degradation temperature $(T d)$ of $150^{\circ} \mathrm{C}$. The bioflocculant appears to hold promise in vast biotechnological applications in a more environmentally friendly and economical manner.
\end{abstract}

Keywords: Virgibacillus sp., bioflocculant, thermostable, polysaccharide.

\section{INTRODUCTION}

Over the past three decades, microbial flocculants have attracted a number of researchers from different countries (Zhang et al., 1999) in response to the questions about the safety of synthetic flocculants. Environmental consideration dictated the development of strong, economically viable and eco-friendly substitutes of conventional synthetic flocculants. If these are ever discharged to the environment they would naturally degrade and allow least net global warming and sustainability (Sharma et al., 2006). In response, various universities and research institutes hone the development of new microbial flocculants (bioflocculants) as their research precedence pursuant to developing new microbial flocculants with better prospects for application (Liang et al., 2010).
Literature searches reveal that a number of microbes are capable of growing in diverse environments and producing secondary metabolites (viz. extracellular polysaccharides, proteins (lectins), lipids) during their growth (Subramanian et al., 2010). For example, Bacillus sp. I-471 (Kumar et al., 2004), Vagococcus sp. W31 (Gao et al., 2006) and Halomonas sp. OKOH (Mabinya et al., 2011) produces polysaccharide bioflocculants. Nocardia amarae YK-1 (Koizumi et al., 1991), Bacillus licheniformis (Shih et al., 2001) and Rhodococcus erythropolis (Tadeka et al., 1991) produce protein flocculant, whereas Arcuadendron sp. TS-4 (Lee et al., 1995), Arathrobacter sp. (Wang et al., 1995), and Halobacillus sp. Mvuyo (Cosa et al., 2012) produce glycoprotein bioflocculant. Extracellular substances that are typically made of polysac- 
charides and proteins are thought to mediate cell-cell interactions or adherence of cells to surfaces (Zhang et al., 2002). They are a diverse and versatile class of materials and act as new biomaterials that have potential applications in many sectors of the economy (Jamil et al., 2008). They are used in food industry as viscosfying, stabilizing and emulsifying agents (Kunmani et al., 2011). Moreover, according to Kumar et al. (2004) and Kanmani et al. (2011), these compounds have become of interest as anti-tumor, anti-viral, and anti-inflammatory agents and as inducers for interferon, platelet aggregation inhibitors and in colony stimulating factor synthesis utilized in various medical and pharmaceutical industries.

Microorganisms produce extracellular substances as flocculants (bioflocculants). Their functions in flocculation and adhesion are similar to some amphoteric polymeric flocculants. These materials virtually possess the desired properties of conventional synthetic flocculants and are biodegradable, environmentally friendly (Sharma et al., 2006), and can be uniformly and reliably produced by fermentation processes ( $\mathrm{He}$ et al., 2010). Although a number of bioflocculants have been evaluated as alternative flocculants, however it has been hard to actualize industrialization of these bioflocculants due to culturing costs and low production yield (Gao et al., 2006). Thus, research has been conducted on bioflocculants in order to reduce bioflocculant production costs and increase flocculant yield and applicability.

According to reported literature, the production of microbial flocculants may be significantly influenced by the culture medium composition and several other physicochemical parameters. Prominent among these are the composition of the growth medium, inoculum size, $\mathrm{pH}$ values, temperature, carbon and nitrogen sources (Suh et al., 1998). In our previous study (Cosa et al., 2011), we reported that, a polysaccharide bioflocculant was produced by Virgibacillus sp. Rob. In this current study, we assessed the bioflocculant production by the bacterium using a different set of culture condition. A series of experiments was undertaken to characterize the bioflocculant in detail, study its flocculating properties and subsequently compare its efficiency with synthetic flocculants.

\section{MATERIALS AND METHODS}

\section{Test bacterium}

The test bacterium was previously isolated from marine sediments of Algoa Bay, South Africa, identified as Virgibacillus sp. Rob by 16S rDNA sequence (Cosa et al., 2011). The organism was preserved in $20 \%$ glycerol at $-80^{\circ} \mathrm{C}$ as part of the culture collections of the Applied and Environmental Microbiology Research Group (AEMREG) at the University of Fort Hare, Alice, South Africa.

\section{Bioflocculant production media}

This present study utilized a medium described by Zhang et al.
(2007) with minor modification. It incorporates additional mineral salts and made use of multiple nitrogen sources from the onset and composed of the following: $20 \mathrm{~g}$ glucose, $0.5 \mathrm{~g}$ urea, $0.5 \mathrm{~g}$ yeast extract, $0.2 \mathrm{~g}\left(\mathrm{NH}_{4}\right)_{2} \mathrm{SO}_{4}, 5 \mathrm{~g} \mathrm{~K}_{2} \mathrm{HPO}_{4}, 2 \mathrm{~g} \mathrm{KH}_{2} \mathrm{PO}_{4}, 0.1 \mathrm{~g} \mathrm{NaCl}$, and $0.2 \mathrm{~g} \mathrm{MgSO}_{4} \cdot 7 \mathrm{H}_{2} \mathrm{O}$ in $1 \mathrm{~L}$ seawater.

\section{Culturing of biofloculant-producing bacterium}

The pre-culture was prepared by inoculating a colony of the strain from the stock culture into a $150-\mathrm{ml}$ flask containing $50 \mathrm{ml}$ bioflocculant-production medium and incubated for $72 \mathrm{~h}$ in a rotatory shaker at $30^{\circ} \mathrm{C}, 160 \mathrm{rpm}$. This was then used as the standard inoculum preparation for all experiments. From the preculture, $0.5 \mathrm{ml}$ was inoculated into a $250-\mathrm{ml}$ flask containing $50 \mathrm{ml}$ production medium. Fermentation was carried out in flasks with a shaking speed of $160 \mathrm{rpm}$ at $30^{\circ} \mathrm{C}$ for $72 \mathrm{~h}$. After the incubation period, the obtained fermentation broth was centrifuged $(8000 \mathrm{~g}$, 30 minto separate the cells. The cell-free supernatant was used as source of bioflocculant and assessed for flocculating activity.

\section{Measurements of flocculating activity}

The flocculating activity test was done in accordance with the method previously described by Kurane et al. (1994). The Kaolin clay was used as suspension material in $4 \mathrm{~g} / \mathrm{l}$ concentration. A control was prepared by replacing the bioflocculant solution with deionized water and measured under similar conditions. Flocculating activity was then expressed in percentage using the formula below:

Flocculating activity $(\%)=[(A-B) / A] \times 100$

Where, $A=$ optical density at $550 \mathrm{~nm}\left(O D_{550}\right)$ of control and $B=$ optical density at $550 \mathrm{~nm}\left(\mathrm{OD}_{550}\right)$ of a sample.

\section{Optimization of culture parameters on bioflocculant production}

To establish the optimum medium culture conditions for enhanced bioflocculant production and flocculating activity, the carbon and nitrogen sources, initial $\mathrm{pH}$ of culture medium and inoculum size (\%, $\mathrm{v} / \mathrm{v})$ were varied.

\section{Carbon and nitrogen source}

To determine a suitable carbon source for bioflocculant production, various carbon sources including: sucrose, fructose, maltose, galactose, xylose, phthalate, sodium acetate and sodium carbonate were incorporated each in basal bioflocculant medium by replacing glucose with same concentration $(20 \mathrm{~g} / \mathrm{l})$. The flasks containing sterilized production medium were then inoculated separately with the bacterial strain and cultivated as described above.

The effect of different organic nitrogen (peptone, tryptone, urea, yeast extract and casein) and inorganic nitrogen (ammonium chloride, ammonium sulphate and sodium nitrate) sources were examined by incorporating each in basal medium replacing the initial multiple nitrogen (urea $(0.5 \mathrm{~g})$ yeast extract $(0.5 \mathrm{~g}),\left(\mathrm{NH}_{4}\right)_{2} \mathrm{SO}_{4}$ (0.2 g) (control).

\section{Initial pH of the medium}

The initial $\mathrm{pH}$ of the culture medium was adjusted to $3.0 ; 4.0 ; 5.0$; $6.0 ; 7.0 ; 8.0 ; 9.0 ; 10.0 ; 11.0$ and 12.0 with $\mathrm{HCl}$ or $\mathrm{NaOH}$. 


\section{Effect of inoculum size}

In $150 \mathrm{ml}$ flasks containing $50 \mathrm{ml}$ of bioflocculant production medium, different inoculum sizes $(0.5,1.0,1.5$ and $2.0 \mathrm{ml})$ of preculture were separately inoculated.

For each of the above experiments, the cultivation temperature was maintained at $30^{\circ} \mathrm{C}$ and the rotary shaking speed was set at $160 \mathrm{rpm}$. The samples were incubated for a period of for $72 \mathrm{~h}$. For each studied experiment, all other constituents were kept constant. After the incubation period, the obtained fermentation broth was centrifuged (8000 g, $30 \mathrm{~min})$ and was assessed for flocculating activity (Yim et al., 2007; Mabinya et al., 2011; Piyo et al., 2011).

\section{Effect of culture time on bioflocculant activity}

The effect of culture time on bioflocculant activity was conducted in accordance with a previous study (Piyo et al., 2011) with minor modifications. The strains were cultured separately under optimal growth conditions. From the seed culture, $2 \%(\mathrm{v} / \mathrm{v})$ was inoculated into $200 \mathrm{ml}$ of bioflocculant production medium in $500 \mathrm{ml}$ flasks (prepared in triplicates) and incubated on a rotatory shaker (160 $\mathrm{rpm})$ at $30^{\circ} \mathrm{C}$. Samples were drawn every $12 \mathrm{~h}$, centrifuged at 8000 $g$ for $30 \mathrm{~min}$ and the cell free supernatant was used to determine the flocculating activity and this was done for a period of five days. The $\mathrm{pH}$ of the broth samples was also measured using a $\mathrm{pH}$ meter (Model: EZDO PL-600 pH meter).

\section{Bulk fermentation, extraction and purification of bioflocculant}

Based on the findings of optimal growth conditions, a $1 \mathrm{~L}$ production medium was prepared in $2 \mathrm{~L}$ flasks, sterilized by autoclave, allowed to cool and inoculated with $2 \%(\mathrm{v} / \mathrm{v})$ test bacterium suspension and incubated at $30^{\circ} \mathrm{C}$ for $72 \mathrm{~h}$ at $160 \mathrm{rpm}$. Purification of the polysaccharide bioflocculant was done in accordance to the methods described elsewhere (Chang et al., 1998; Chen et al., 2002; Cosa et al., 2011) with slight modification. Briefly, after $72 \mathrm{~h}$ of fermentation, the culture solution was centrifuged at $4,600 \mathrm{rpm}$ for $30 \mathrm{~min}$ to remove bacterial cells. One volume of distilled water was added to the upper phase and centrifuged at 4,600 rpm for $15 \mathrm{~min}$ to remove insoluble substances. To the supernatant, two volumes of ethanol were added, and the mixed solution was stirred and left to stand at $4^{\circ} \mathrm{C}$ for $12 \mathrm{~h}$. The precipitate was vacuum dried to obtain the crude biopolymer. The crude product was directly dissolved in distilled water to yield a solution, to which one volume of the mixed solution of chloroform and $n$-butyl alcohol $(5: 2 \mathrm{v} / \mathrm{v})$ was added. After stirring, the mixture was set aside for $12 \mathrm{~h}$ at room temperature (about $20^{\circ} \mathrm{C}$ ). The upper phase was centrifuged at $4600 \mathrm{rpm}$ for 15 min and two volumes of ethanol were added to recover the precipitate, vacuum-dried and then re-dissolved in distilled water, dialyzed against de-ionized water overnight and then vacuum dried to obtain a purified bioflocculant.

\section{Physical and chemical analysis of purified bioflocculant}

\section{Composition analysis of purified bioflocculants}

The measurement of polysaccharide content was done using the method of Dubois et al. (1956) with glucose as a standard. The total protein content was determined using the Folin-Lowry method with bovine serum albumin (BSA) as a standard (Lowry et al., 1951). The presence of uronic acid content was measured by carbazole method as described by Cesaretti et al. (2003).

\section{Scanning electron microscopic observations on bioflocculant}

Few drops of bioflocculant powder were dropped and fixed on the iron stub. The fixed specimen was gold coated and examined with a (JEOL - JSM-6390LV, Japan) Scanning electron microscope.

\section{FTIR analysis}

The polysaccharide bioflocculant was characterized by using Fourier Transform Infrared Spectrophotometer (Perkin Elmer System 2000, England). The dried bioflocculant powder was ground with potassium bromide (Kbr) and pressed into pellets for FTIR spectral measurement in the frequency range of $4000-400 \mathrm{~cm}^{-1}$.

\section{Thermal stability of bioflocculant}

Thermo-stability of purified bioflocculant was examined by measuring residual flocculating activity. The bioflocculant solutions were incubated in water bath fixed at 50,80 and $100^{\circ} \mathrm{C}$ periods up to $30 \mathrm{~min}$. Samples were drawn at appropriate time intervals and then analyzed for residual flocculating activity as also previously described by Gong et al. (2008).

\section{Thermo-gravimetric analysis}

The degradation temperature of the bioflocculant was studied using Thermo-gravimetric (STA 449/C Jupiter Netz, Germany; Perkin Elmer TGA7 Thermogravimetric Analyzer, USA) instrument. The measured bioflocculant was heated from 22 to $900^{\circ} \mathrm{C}$ at a rate constant of $10^{\circ} \mathrm{C} \mathrm{min}{ }^{-1}$ under constant flow of nitrogen gas.

\section{Determination of bioflocculant dosage using jar test}

Jar-test experiments were carried out using $1 \mathrm{~L}$ six place paddle stirrer (Model: FC6S VELP Scientifica, Europe) to determine the optimum dose of the purified bioflocculant for the clarification of kaolin clay suspension $(4 \mathrm{~g} / \mathrm{l})$ at neutral $\mathrm{pH}$. Different concentrations of the purified bioflocculant (powder) ranging from 0.1 to $1 \mathrm{mg} / \mathrm{ml}$ were prepared. The operational procedures included rapid mixing at $180 \mathrm{rpm}$ for $1 \mathrm{~min}$, the flocculation period at $45 \mathrm{rpm}$ for $3 \mathrm{~min}$ and the sedimentation was 5 min as reported by Lee et al. (2001) with minor modifications. After settling, the upper phase was sampled to measure flocculating activity

\section{Effect of $\mathrm{pH}$ on flocculation activity of the purified bioflocculants}

To evaluate the effect of $\mathrm{pH}$ on flocculating activity of the purified bioflocculants, the $\mathrm{pH}$ of the bioflocculant solutions were adjusted to $3.0,4.0,5.0,6.0,7.0,8.0,9.0,10.0$, and 11.0 by the addition of $\mathrm{HCl}$ or $\mathrm{NaOH}$.

\section{Effects of cation dependency on flocculating activity of the purified bioflocculant}

To investigate this effect, $(+)$ cation $(3 \mathrm{ml})$ and bioflocculant $(2 \mathrm{ml})$ were added to the kaolin suspension. $\mathrm{CaCl}_{2}$ solution previously used as stimulating agent was replaced by various metal salt solutions. Potassium chloride $(\mathrm{KCl})$, sodium chloride $(\mathrm{NaCl})$, and lithium chloride ( $\mathrm{LiCl}$ ) acted as monovalent cation source; manganese 
Table 1. Effect of carbon sources and nitrogen sources on bioflocculant activity.

\begin{tabular}{lclc}
\hline Carbon source & FA (\%) & nitrogen source & FA (\%) \\
\hline Glucose & $91.8 \pm 3.08^{\mathrm{a}}$ & Peptone & $79.9 \pm 1.47^{\mathrm{b}}$ \\
Maltose & $78.8 \pm 1.89^{\mathrm{b}}$ & Tryptone & $78.9 \pm 4.1^{\mathrm{b}}$ \\
Galactose & $74.02 \pm 2.82^{\mathrm{b}}$ & Casein & $70.8 \pm 3.51^{\mathrm{a}, \mathrm{b}}$ \\
Fructose & $64.36 \pm 2.18^{\mathrm{c}}$ & Yeast & $69.8 \pm 2.53^{\mathrm{a}, \mathrm{b}}$ \\
Sucrose & $58.25 \pm 5.24^{\mathrm{c}}$ & Urea & $67.9 \pm 1.51^{\mathrm{a}, \mathrm{b}}$ \\
Xylose & $15.5 \pm 4.36^{\mathrm{d}}$ & Ammonium sulphate & $78.9 \pm 3.04^{\mathrm{b}}$ \\
Sodium carbonate & $72.15 \pm 5.16^{\mathrm{e}}$ & Ammonium nitrate & $75.3 \pm 4.1^{\mathrm{a}, \mathrm{b}}$ \\
Sodium acetate & $49.56 \pm 2.87^{\mathrm{f}}$ & Ammonium chloride & $37 \pm 1.01^{\mathrm{c}}$ \\
Phyltalate & $42.53 \pm 2.77^{\mathrm{f}}$ & Complex nitrogen (Urea+ Yeast extract+ $\left.\left(\mathrm{NH}_{4}\right)_{2} \mathrm{SO}_{2}\right)$ & $91.8 \pm 3.08^{\mathrm{a}}$ \\
\hline
\end{tabular}

The results are represented as mean values of triplicates \pm Standard deviation. Percentage flocculating activity (FA) with different alphabets are significantly $(p<0.05)$ different.

phosphate $\left(\mathrm{MnPO}_{4}\right)$ and magnesium chloride $\left(\mathrm{MgCl}_{2}\right)$ acted as divalent cation source; and aluminium chloride $\left(\mathrm{AlCl}_{3}\right)$ and iron (III) sulfate $\left(\mathrm{FeSO}_{4}\right)$ acted as trivalent cation source. The flocculating activity was measured as mentioned above (Zulkeflee et al., 2012).

\section{Statistical analysis}

Treatments used for each experiment were done in minimum of three replicates with mean and standard deviation values determined. Microsoft excel office 2007 version was used to determine means and standard deviations. Statistically significant differences of the percentage bioflocculant activity among the treatment means were analysed using the analysis of variance (ANOVA) test (Minitab Student Release 12) where differences were considered significant at 0.05 confidence level.

\section{RESULTS}

\section{Factors affecting the bioflocculant activity}

\section{Effect of carbon and nitrogen sources}

The effect of various carbon and nitrogen sources on bioflocculant activity was carried out and results are depicted in Table 1. The effect of various carbon sources showed that glucose followed by maltose, galactose and sodium carbonate were best favoured carbon sources with flocculating activity of $91.8,78.8,74.02$ and $72.15 \%$ respectively. On the other hand, phthalate was the least preferred carbon source with $42.53 \%$ flocculating activity. With respect to nitrogen source, Table 1 shows that peptone $(79.9 \%$ flocculating activity) followed by tryptone (78.9\% flocculating activity), casein (70.8\% flocculating activity) and yeast (69.8\% flocculating activity) were the best nitrogen sources while ammonium chloride (37\% flocculating activity) was the least favourable nitrogen source. Although, higher flocculating activity of $91.8 \%$ was obtained for the test bacteria when a multiple nitrogen source consisting of urea, yeast extract and ammonium sulphate was used.

\section{Effect of initial $\mathrm{pH}$ and inoculum size}

The effect of initial $\mathrm{pH}$ of the medium was examined over the $\mathrm{pH}$ range of 3-12 and results are shown in Figure 1. From the results of this study, initial medium $\mathrm{pH} 3,4,5$ and 6 resulted in bioflocculant production with flocculating activities of $83,72.5,73.8$ and $73.6 \%$, respectively; however alkaline $\mathrm{pH} 10$ showed optimum flocculating activity of $85.8 \%$.

Figure 2 shows that inoculums size of $2 \%(\mathrm{v} / \mathrm{v})$ resulted in optimum production of biofloculant (flocculating activity $91.8 \%)$. Subsequent increases in inoculum size resulted in almost constant activity without further increase in flocculating activity.

\section{Effect of fermentation duration}

With regards to the bioflocculant production kinetics (Figure 3), flocculating activity of about $82 \%$ was observed within the initial $12 \mathrm{~h}$ of fermentation and remained relatively constant with time but attained a peaked (87\% flocculating activity) in $72 \mathrm{~h}$ after which flocculating activity declined.

\section{Physical and chemical analysis of bioflocculant}

\section{Bioflocculant yield}

After purification, a total bioflocculant yield of $2.43 \mathrm{~g}$ (Table 2) was recovered from $1 \mathrm{~L}$ culture broth and was slightly better when compared with other different yields of bioflocculant production as shown in Table 2.

\section{Chemical composition analysis of the bioflocculant}

The chemical properties of the purified bioflocculant showed the proportions of the neutral sugar content as 


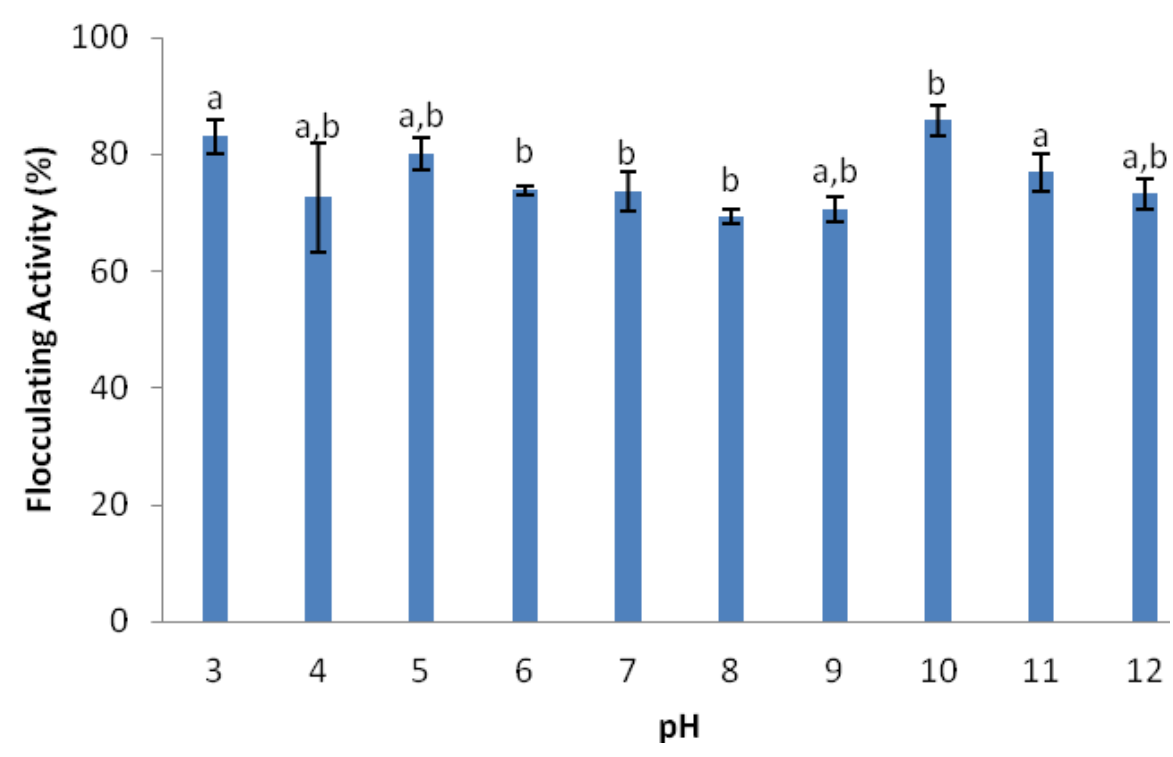

Figure 1. Effect of initial $\mathrm{pH}$ on bioflocculant activity of Virgibacillus sp. Rob. Percentage flocculating activity with different letters $(a, b)$ are significantly $(p<0.05)$ different.

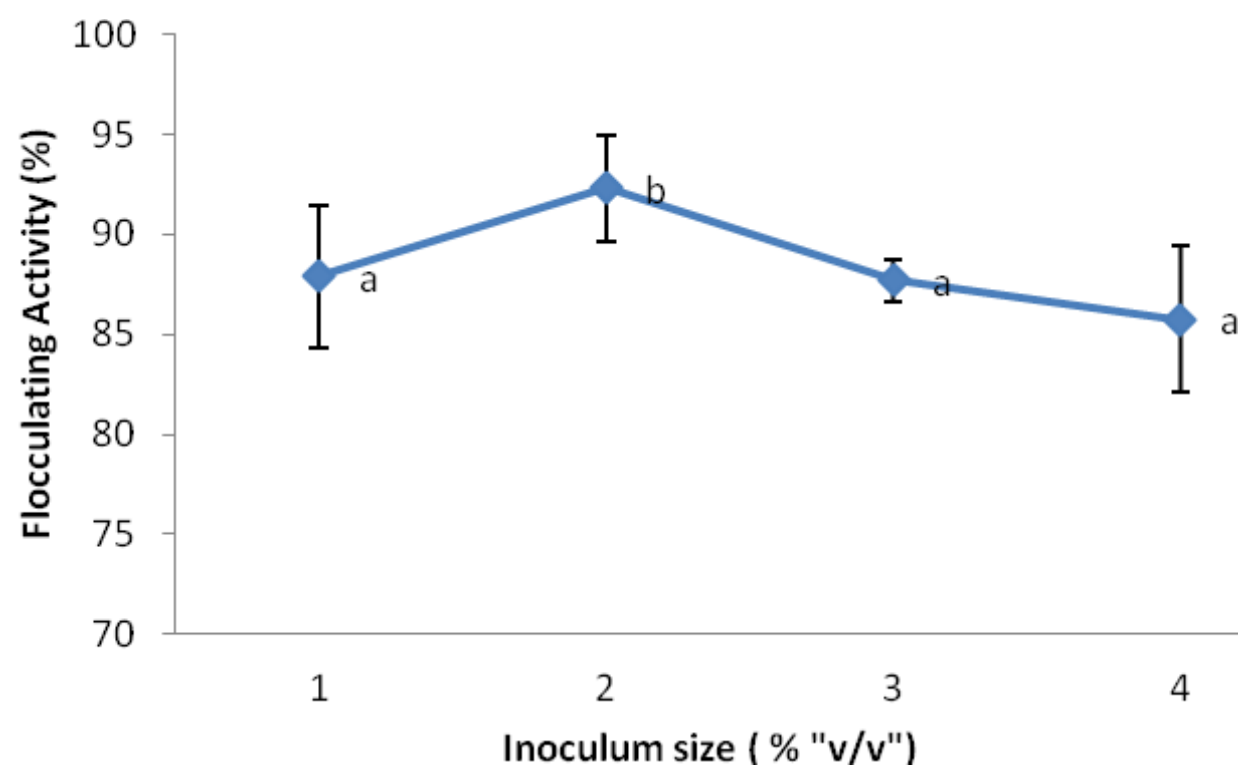

Figure 2. Effect of inoculum size on bioflocculant activity of Virgibacillus sp. Rob. Percentage flocculating activity with different letters $(a, b)$ are significantly $(p<0.05)$ different.

$6.6 \%$ while uronic acids were $87.7 \%$ with no protein detected.

Further details of the elemental composition revealed the bioflocculant to contain $\mathrm{C}, \mathrm{N}, \mathrm{O}, \mathrm{P}$ major elements, while $\mathrm{S}$ was present as minor element on the surface of the bioflocculants with $3.82,7.43,40.7,1.69,11.69$ weight percentages respectively.

\section{SEM observations}

Surface morphology structure of the bioflocculant as revealed by Scanning Electron Microscopy (SEM) showed that the bioflocculant was whitish in color and porous (Figure 4i). On the other hand, the kaolin particles before flocculation are fine and scattered as shown in 


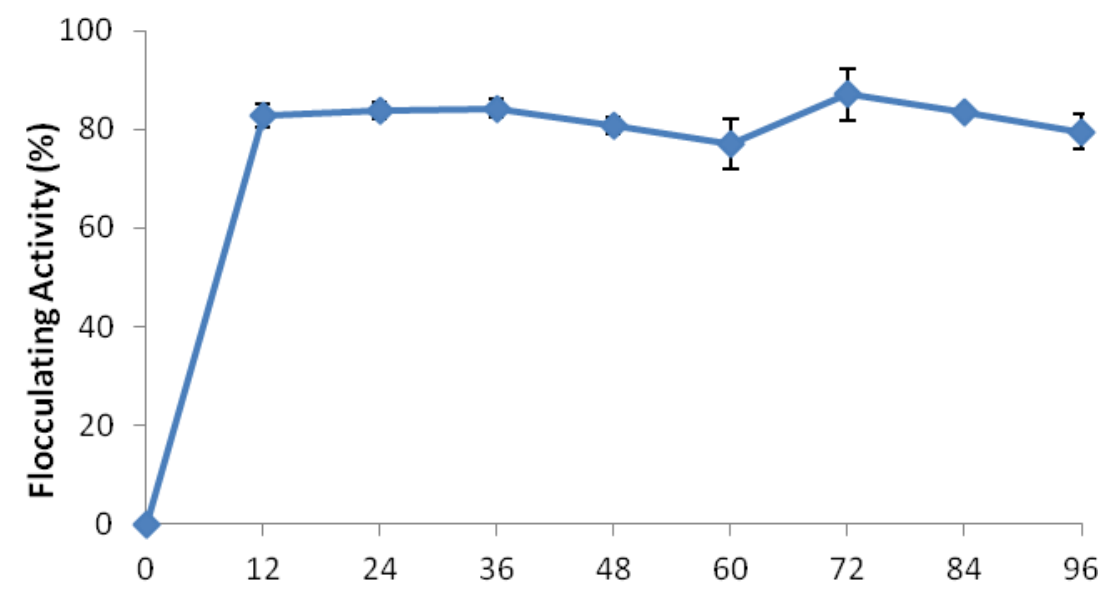

Time of bioflocculant production

Figure 3. Time course assay of bioflocculant production by Virgibacillus $\mathrm{sp}$. Rob

Table 2. Comparison of the purified bioflocculant produced by Virgibacillus sp. Rob with other bioflocculants.

\begin{tabular}{|c|c|c|c|c|}
\hline Strain & $\begin{array}{c}\text { Bioflocculant } \\
\text { yield }(g / L)\end{array}$ & $\begin{array}{l}\text { Carbon/Nitrogen } \\
\text { sources in fermentation }\end{array}$ & Components & Reference \\
\hline $\begin{array}{l}\text { Enterobacter } \\
\text { cloacae WD7 }\end{array}$ & 2.27 & $\begin{array}{l}\text { Glucose/Sucrose, } \\
\left(\mathrm{NH}_{4}\right)_{2} \mathrm{SO}_{4}\end{array}$ & $\begin{array}{l}\text { acidic hetero- } \\
\text { polysaccharide }\end{array}$ & $\begin{array}{l}\text { Prasertsan et al., } \\
2006\end{array}$ \\
\hline $\begin{array}{l}\text { Proteus mirabilis } \\
\text { TJ-1 }\end{array}$ & 1.33 & Glucose, peptone & $\begin{array}{l}\text { Acid polysaccharide } \\
\text { and protein }\end{array}$ & Xia et al., 2008 \\
\hline Bacillus firmus & 1.36 & $\begin{array}{l}\text { Glucose, peptone, yeast } \\
\text { extract }\end{array}$ & Acidic polysaccharide & Chen et al., 2002 \\
\hline $\begin{array}{l}\text { Bacillus sp. Strain } \\
\text { F19 }\end{array}$ & 1.47 & Sucrose, yeast extract & Mainly polysaccharide & Zheng et al., 2008 \\
\hline Aeromonas sp. & 2.25 & $\begin{array}{l}\text { Sucrose, yeast extract, } \\
\text { ammonium sulphate, urea }\end{array}$ & Not specified & Li et al., 2007 \\
\hline $\begin{array}{l}\text { Vagococcus sp. } \\
\text { strain W31 }\end{array}$ & 2.3 & $\begin{array}{l}\text { Glucose, ammonium } \\
\text { sulphate }\end{array}$ & Polysaccharide & Gao et al., 2006 \\
\hline $\begin{array}{l}\text { Virgibacillus sp. } \\
\text { Rob }\end{array}$ & 2.43 & Glucose, peptone & Polysaccharide & Our study \\
\hline
\end{tabular}

Figure 4(ii) while after flocculation, the bioflocculant and its kaolin interaction were coupled as represented in Figure 4(iii).

\section{Functional groups of the purified bioflocculants}

An analysis of the functional groups of purified bioflocculant from Virgibacillus sp. Rob showed a broad stretching peak at $3414.51 \mathrm{~cm}^{-1}$ which is a common characteristic of hydroxyl and amino groups. Two peaks at 2374.75 and $2063.74 \mathrm{~cm}^{-1}$, weak peaks observed at 1638.43 and $1619.13 \mathrm{~cm}^{-1}$ suggestive of the presence of carboxyl groups with $\mathrm{C}=\mathrm{O}$ in an amide group and $1400.88 \mathrm{~cm}^{-1}$ and small absorption peaks were exhibited around 1000 to $1137 \mathrm{~cm}^{-1}$ attributed to the asymmetrical stretching vibration of a C-O-C ester linkage.

\section{Analysis of thermal stability of bioflocculant}

The effect of heat on the bioflocculant was investigated at three different temperatures $\left(50,80\right.$ and $\left.100^{\circ} \mathrm{C}\right)$ for 30 min each. The bioflocculant retained about 84,80 and $79 \%$ flocculating activity at 50,80 and $100^{\circ} \mathrm{C}$ respectively although these variations were not significantly different 

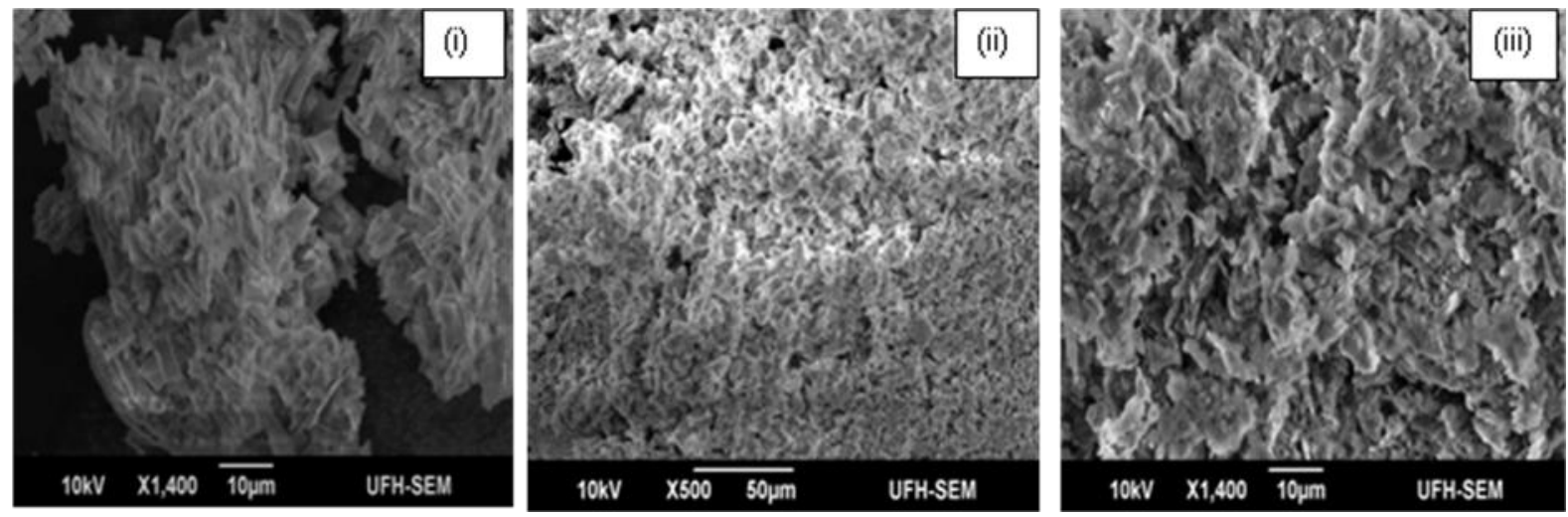

Figure 4. SEM images of (i) kaolin clay (ii) bioflocculant by Virgibacillus sp. Rob (iii) kaolin clay flocculated by the extracted bioflocculant.

$(p<0.05)$

\section{Thermo-gravimetric analysis of purified bioflocculant}

The pyrolysis property of the purified bioflocculant was studied using thermo-gravimetric analysis (TGA). A degradation temperature $\left(T_{\mathrm{d}}\right)$ of $150^{\circ} \mathrm{C}$ was observed (Figure 7). An initial weight loss of about $2 \%$ in the bioflocculant was found between 110 and $140^{\circ} \mathrm{C}$. Further increase in temperature to $580^{\circ} \mathrm{C}$ resulted in about $20 \%$ reduction in mass fraction thereafter a gradual decrease in mass weight was observed.

\section{Flocculating properties of purified bioflocculant}

\section{Effect of bioflocculant concentrations}

Jar-test experiment revealed that flocculating activity increased with the increasing concentration of biofloculant and a peak of $88.7 \%$ was attained at a dose of 0.3 $\mathrm{mg} / \mathrm{ml}$. Thereafter, as bioflocculant concentration increased beyond this optimum, flocculating activity decreased (Figure 8).

\section{Effect of $\mathrm{pH}$ on flocculation by the purified bioflocculant}

The effect of $\mathrm{pH}$ on flocculating activity of the purified bioflocculant was examined using $0.3 \mathrm{mg} / \mathrm{ml}$ concentration of the purified bioflocculant and $\mathrm{Ca}^{2+}$ as the mediating cation. At acidic conditions, the flocculating activity was maintained between 71.2 to $82.9 \%$ while at alkaline conditions, the flocculation activity was between 33.6 to $79.8 \%$. However, the highest flocculation activity was obtained at neutral $\mathrm{pH}(84 \%)$.

\section{Effect of various cations on flocculation}

Experiments on effect of various cations demonstrated that, flocculating activity was altered in presence of some cations (Figure 10). Flocculation was enhanced in the presence of $\mathrm{Ca}^{2+}, \mathrm{Al}^{3+}, \mathrm{Mn}^{2+}$ and $\mathrm{Mg}^{2+}$ with $91.7,83.2$, 68.2 and $62.9 \%$ flocculating activity, respectively. On the other hand, $\mathrm{Fe}^{3+}, \mathrm{Li}^{+}, \mathrm{K}^{+}$and $\mathrm{Na}^{+}$, showed least and/or no flocculating activity (Figure 10).

\section{Comparative analysis of flocculation efficiencies of different chemical flocculants and the biofloculants}

The purified bioflocculant was more efficient than the conventional inorganic ferric chloride and alum, as well as polyethylimine flocculants as revealed by the optimum dose of $0.3,0.1,0.2$ and $0.2 \mathrm{mg} / \mathrm{ml}$ compared to $0.3,0.8$ and $1 \mathrm{mg} / \mathrm{ml}$ for polyethylimine, ferric chloride and alum respectively. The bioflocculants were however less efficient than polyacrylamide which had an optimum dosage of $0.1 \mathrm{mg} / \mathrm{ml}$ (Table 3).

\section{DISCUSSION}

In our previously study (Cosa et al., 2011), Virgibacillus $\mathrm{sp}$. Rob was established as a bioflocculant producing bacteria. Some preliminary culture conditions were examined. Conversely, in this present study, additional sources (carbon and nitrogen sources), other parameters $(\mathrm{pH}$, inoculum size and thermal stability) and cultivation time that are known to indirectly affect the bioflocculant yield and activity were investigated, the fundamental rationale been to improve upon the bioflocculant production efficiency of the bacteria.

Bioflocculant production is affected by numerous factors, such as the constituents of the culture medium 
Table 3. Comparison of bioflocculant efficiency with some chemical flocculants.

\begin{tabular}{lcc}
\hline Flocculant & Dosage (mg/ml) & Turbidity reduction (\%) \\
\hline Polyacrylamide & 0.3 & 95.2 \\
Bioflocculant & 0.3 & 89.0 \\
Polyethylimine & 0.1 & 82.6 \\
Ferric chloride & 0.8 & 74.5 \\
Alum & 1 & 70.9 \\
\hline
\end{tabular}

and the culture conditions. Since the carbon source plays a very significant role in growth, particularly in extraceIlular polysaccharide production, several sugars were investigated and results are articulated in Table 1. Flocculating activity was significantly higher $(p<0.05)$ when glucose (flocculating activity $91.8 \%$ ) was used as sole source of carbon compared to the other carbon sources. This confirms our previously reported study (Cosa et al., 2011) although in this case the percentage flocculating activity increased. The increase may be due to the supplemented nitrogen sources or fermentation period. Glucose had been vastly documented as fine substrate for bioflocculant production (Suh et al., 1998). Furthermore, a literature search shows that numerous bioflocculant producing bacteria prefer organic carbon sources for bioflocculant production, thus supporting the observation for the Virgibacillus sp. Rob. For instance, Gong et al. (2003) concluded that sucrose, maltose, xylitol, lactose and glucose are suitable substrates for flocculant production by Paenibacillus polymyxa BY-28, with glucose being the best.

Furthermore, we investigated the influence of nitrogen source on bioflocculant production by the bacteria with glucose as carbon source. In place of the multiplenitrogen sources (yeast, urea and ammonium sulphate) used, individual nitrogen source was incorporated, however the concentration used amounted to the sum of that multiple-nitrogen source used in the previous report. Results revealed that flocculating activity was highest when peptone was used, though not significantly different in comparison to tryptone, ammonium nitrate and ammonium sulphate (Table 1). Organic nitrogen sources are reported to be more suitable for bioflocculant production but a complex nitrogen substrate consisting of urea, yeast extract and $\left(\mathrm{NH}_{4}\right)_{2} \mathrm{SO}_{4}$ enhanced cell activity more significantly and was better suitable for the bioflocculant production than the other nitrogen sources tested. In line with our results, Gong et al. (2008) also found that a complex nitrogen source consisting of beef extract and urea is better than a single inorganic or organic nitrogen sources. Kurane and Matsuyama (1994), reported a bioflocculant production by a mixed culture in which the production medium incorporated a combination of ammonium sulphate and yeast extract as the nitrogen sources. On the contrary, the literature (Gandhi et al., 1998; Hwang et al., 2003; Wang et al., 2011) reports that organic nitrogen sources are more favourable for bioflocculant production and in addition are more easily absorbed by the cells than the inorganic nitrogen sources.

Based on literature (Zhang et al., 2007), the initial $\mathrm{pH}$ of the production medium determines the electric charge of the cells and the oxidation-reduction potential, which can affect absorption of nutrients and enzymatic reaction of test bacteria. Hence, altering the $\mathrm{pH}$ may affect the medium composition thus resulting in varied bioflocculant activities. As illustrated in the results, it is evident that the acidic, neutral to alkaline conditions supported bioflocculant production (Figure 1). Alkaline $\mathrm{pH} 10$ appeared to be optimum in contrast to $\mathrm{pH} 11$ reported in the previous study (Cosa et al., 2011). Although the initial pH of the production medium determines the electric charge of the cells and the oxidation-reduction potential which consecutively can influence nutrient absorption and enzymatic reaction, this influence differs with each studied organism (Salehizadeh and Shojaosadati, 2001). Mabinya et al. (2011) reported that $\mathrm{pH} 7$ was optimal for bioflocculant production by Halomonas sp. $\mathrm{OKOH}$. Kurane et al. (1994) documented that for bioflocculant production by Rhodococcus erythropolis, alkaline $\mathrm{pH}$ (8.0-9.5) was most favourable. In the case of the present study, the bioflocculants from Virgibacillus sp. was produced maximally under high alkaline conditions

Amongst a number of bacteria's physiological properties, inoculum size may play a significant role in biological development (Gancel et al., 1994). According to documented literature (Chen et al., 2008; Wang et al., 2011) the inoculum size and liquid volume may play a vital role in cell reproduction and bioflocculant production. Experimental results revealed that inoculum size had an effect on bioflocculant production and activity. When the inoculum size was increased a decrease in flocculating activity was observed, while at $2 \%$ inoculum size the maximum flocculating activity was achieved, reaching a plateau thereafter (Figure 2). The obtained flocculating activity at $2 \%$ inoculum size was significantly higher $(p<$ $0.05)$ than other inoculum sizes tested. The optimal inoculum size allowed the adaptation of strains to the production medium thereby promoting the production of bioflocculants (Li et al., 2009). In addition, the plateauing in flocculating activity may be attributed to excess inoculum size, which causes an excessive niche overlap, resulting in inhibition of further bioflocculant production due to the limit of nutrient distribution (Salehizadeh and Shojaosadati, 2001; Zhang et al., 2012). Similar phenomenon was reported for bioflocculant production by Serratia ficaria (Gong et al., 2008).

When the bioflocculant production kinetics was investigated, flocculating activity increased with culture time, subsequently flocculating activity declined (Figure 
3). The decline on flocculating activity may be due to the enzymatic degradation and cessation of bioflocculant production (Zhu et al., 2011). The bioflocculant was deduced an extracellular product since it was extracted from culture medium free of cells (Zhu et al., 2011). Similar results were reported by Li et al. (2007) whereby Aeromonas sp. bioflocculant reached its flocculating activity maxima after 3 days of fermentation. Prasertsan et al. (2006) reported Enterobacter cloacae WD7 exhibiting the highest flocculating activity after $72 \mathrm{~h}$ of cultivation.

As noted in Piyo et al. (2011), cultivation time for bioflocculant release into the medium varies with diverse microorganisms. Bacillus licheniformis CGMCC 2876 showed relatively short fermentation period of $40 \mathrm{~h}$ (Xiong et al., 2010). The observed corresponding $\mathrm{pH}$ to the profile of flocculating activity, a slight increase in $\mathrm{pH}$ levels from 10.2 to 10.5 in the first $12 \mathrm{~h}$; thereafter the $\mathrm{pH}$ was nearly stable the fermentation period (data not shown). This increase did not vary significantly and may be as a result of excretion of extracellular materials resulting from the partial degradation of the bioflocculant (Mabinya et al., 2011).

After the extraction and purification, our recovered bioflocculant yield was about $90 \%$ more than obtained in our previous report (Cosa et al., 2011). Different yields in bioflocculant production have been well documented as shown in Table 2 and our bioflocculant yield differed from the other microorganisms from those reported in literature (Table 2).

The surface morphology structure of the studied bioflocculant and its interaction with kaolin clay suspension by Scanning Electron Microscopy (SEM) showed that the bioflocculant (Figure 4) was conversely different from the crystal-linear structure of bioflocculant TJ-F1 proposed by Xia et al. (2008). However, our findings were similar to that reported by Kumar et al. (2004). Prior to flocculation, the kaolin particles were dispersed, during the process of coagulation-flocculation the scattered kaolin particles were probably knit and adsorbed onto the binding sites of the bioflocculants which thus aggregated, forming larger flocs and leading to rapid sedimentation due to gravity (Xiong et al., 2010; Wang et al., 2011).

When a chemical composition analysis of the purified bioflocculant was carried out to identify the main chemical constituents, the results showed that it was mainly acidic polysaccharide with no amount of protein present. The results revealed it to be predominantly made up of uronic acids. A number of bacterial strains that produce (acidic) polysaccharide bioflocculants have been well documented. As example, Bacillus firmus amongst others was reported to produce an acidic polysaccharide bioflocculant (Chen et al., 2002). Consequently, the polysaccharide in the purified bioflocculant may explicate the observed high flocculating activities.
When further analysis was conducted for elements of the purified bioflocculant the findings revealed the presence of $\mathrm{C}, \mathrm{N}, \mathrm{O}, \mathrm{S}$, and $\mathrm{P}$ on the surface of the bioflocculants. The presence of the non-sugar components is typically smaller, though it may give flexibility and stabilize the bioflocculant. In agreement with our findings, Gosh et al. (2009) reported the presence of $\mathrm{C}$ and $\mathrm{N}$ in quantities of $14.3 \%, 0.64 \%$ respectively while $S$ and $P$ were reported as trace elements on the surface of the bioflocculant produced by Klebsiella terrigena.

FTIR spectrophotometry revealed the presence of some functional groups in the purified bioflocculant. As shown in Figure 5, a broad stretching peak was observed at $3414.51 \mathrm{~cm}^{-1}$ which was indicative of hydroxyl groups and amine groups. This may also be as a result of vibration of $-\mathrm{OH}$ or $-\mathrm{NH}$ present in the sugar ring (Xiong et al., 2010). Two peaks at 2374.75 and $2063.74 \mathrm{~cm}^{-1}$ is indicative of $\mathrm{C}-\mathrm{H}$ alphatic bonds ( $\mathrm{He}$ et al., 2010). The weak peaks observed at 1638.43, $1619.13 \mathrm{~cm}^{-1}$ and $1400.88 \mathrm{~cm}^{-1}$ are indicative of carboxyl groups. The peaks exhibited around 1000 to $1137 \mathrm{~cm}^{-1}$ are suggestive of uronic acids (Kumar et al., 2004), and the weak peaks $\left(873.58 \mathrm{~cm}^{-1}\right)$ identified are indicative of the presence of sugar derivatives. Also according to Xiong et al. (2010), the small absorption peaks may be suggestive of $\beta$ glycosidic linkages amid the sugar monomers. Hence, the FTIR spectrophotometric analysis suggests the presence of carboxyl, hydroxyl, and amine groups which are major adsorptive forces of the bioflocculant and crucial for the process of flocculation (Wang et al., 2011). The observation also suggests the carboxyl groups as the binding sites for cation allowing improved flocculation. For example, the $\mathrm{OH}, \mathrm{COOH}$, and $\mathrm{COO}^{-}$groups may link with the $\mathrm{H}^{+}$and $\mathrm{OH}^{-}$present on the surface of the particles forming hydrogen bonds when the bioflocculant chains approach the particles' surface (Zheng et al., 2008). Our findings also revealed the bioflocculant to contain functional groups similar to those reported in other studies (Wang et al., 2007; Yim et al., 2007; Feng et al., 2008). Moreover, these functional groups are preferred for the flocculation process similar to that observed in polyelectrolytes such as anionic polyacrylamides (Bolto and Gregory, 2007). Furthermore, the functional groups particularly carboxyl could also work as functional moieties to generate new and/or modified polysaccharide variants using different approaches, including polymer engineering or novel formulation designing, by linking the polysaccharide with other synthesized polymers (Yim et al., 2007).

When the effect of heat on the bioflocculant was investigated at three different temperatures $(50,80$ and $100^{\circ} \mathrm{C}$ ) the results suggested that heat had little impact on the physical and chemical properties of the bioflocculant up to $100^{\circ} \mathrm{C}$ (Figure 6). The thermal stability of the bioflocculant could be as a result of the 


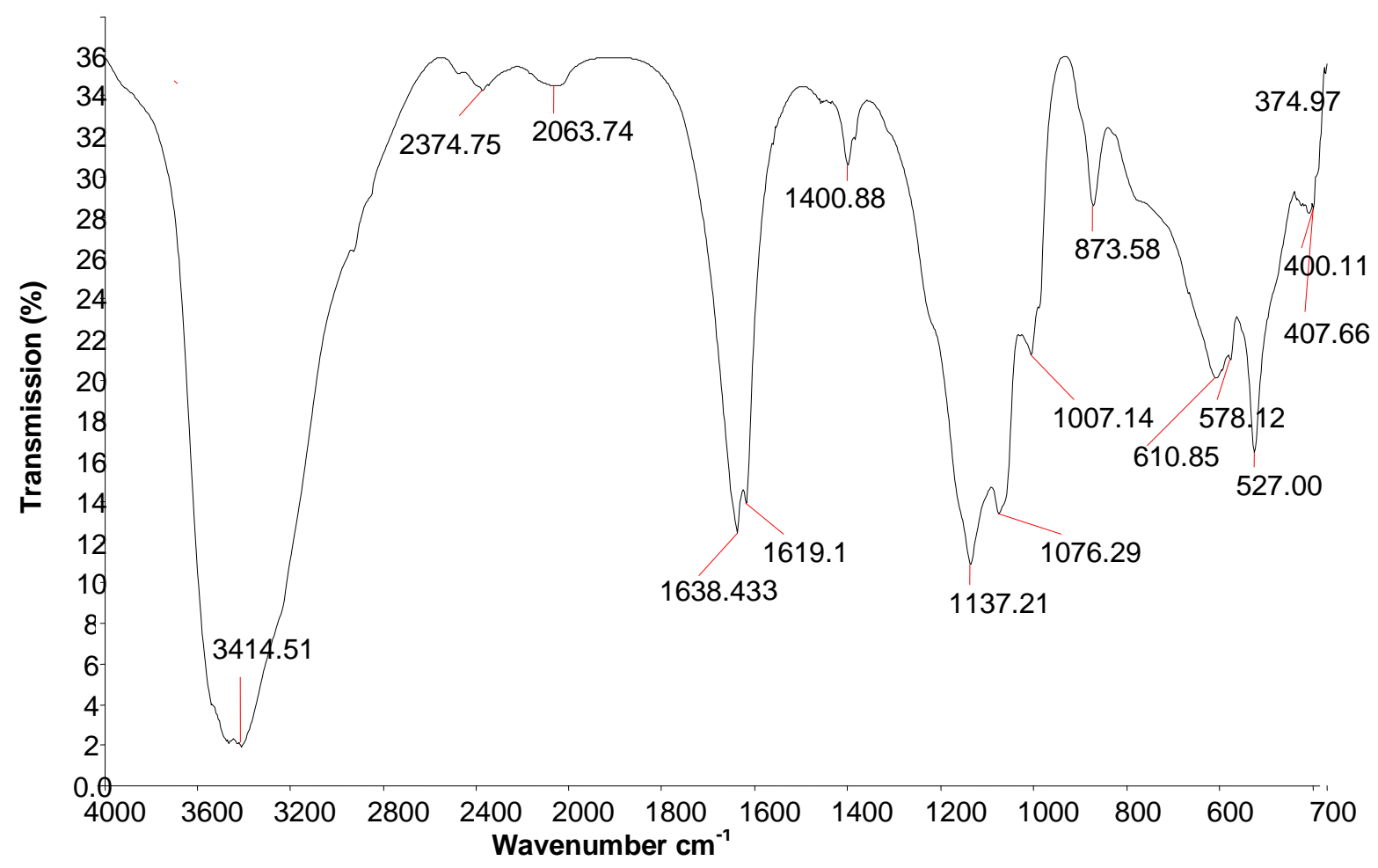

Figure 5. Infrared spectra of purified polysaccharide bioflocculant produced by Virgibacillus sp. Rob.

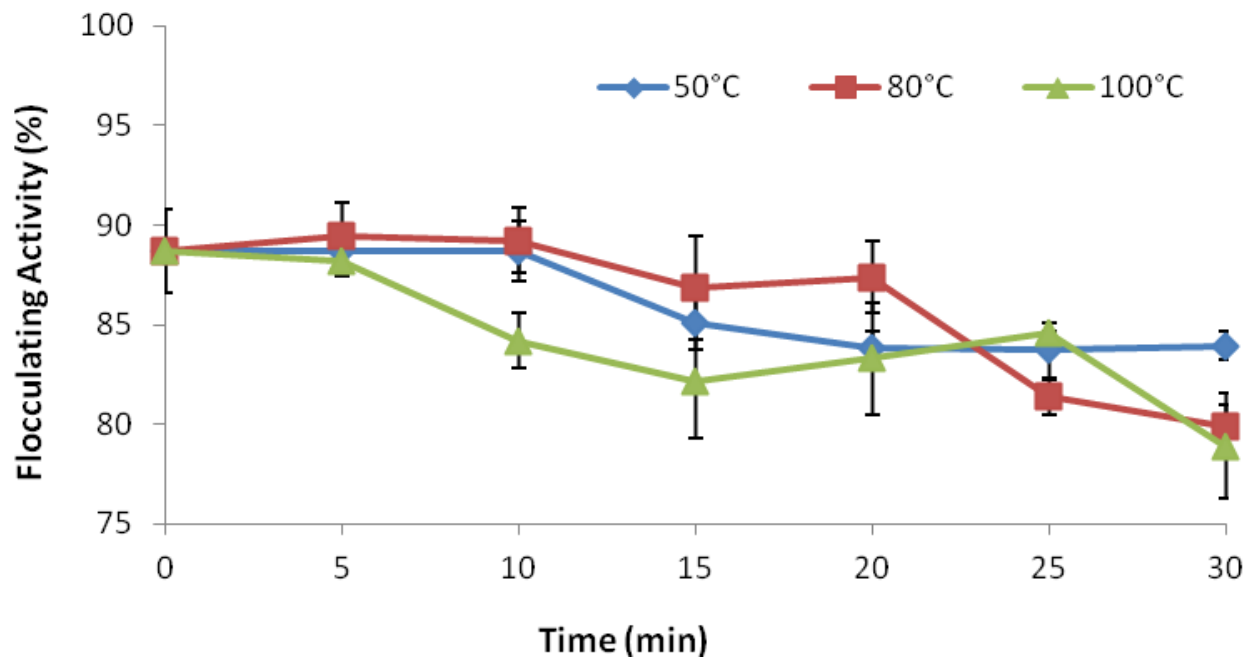

Figure 6. Thermal stability of the purified polysaccharide bioflocculant.

polysaccharide backbone of the bioflocculant (Gong et al., 2008; Lu et al., 2005). Corroborating our findings, Gong et al. (2008) and Lu et al. (2005) reported bioflocculants produced by Serratia ficaria and Enterobacter aerogenes as thermally stable. However in a study reported by Lian et al. (2008), the bioflocculant produced by Bacillus mucilaginosus was thermally stable but beyond $70^{\circ} \mathrm{C}$ noticeable reduction in the flocculation ratio that falls to about $70 \%$ was observed.

When the pyrolysis property of the purified bioflocculant was studied, a degradation temperature $\left(T_{d}\right)$ of $150^{\circ} \mathrm{C}$ was observed which further corroborated the thermal 


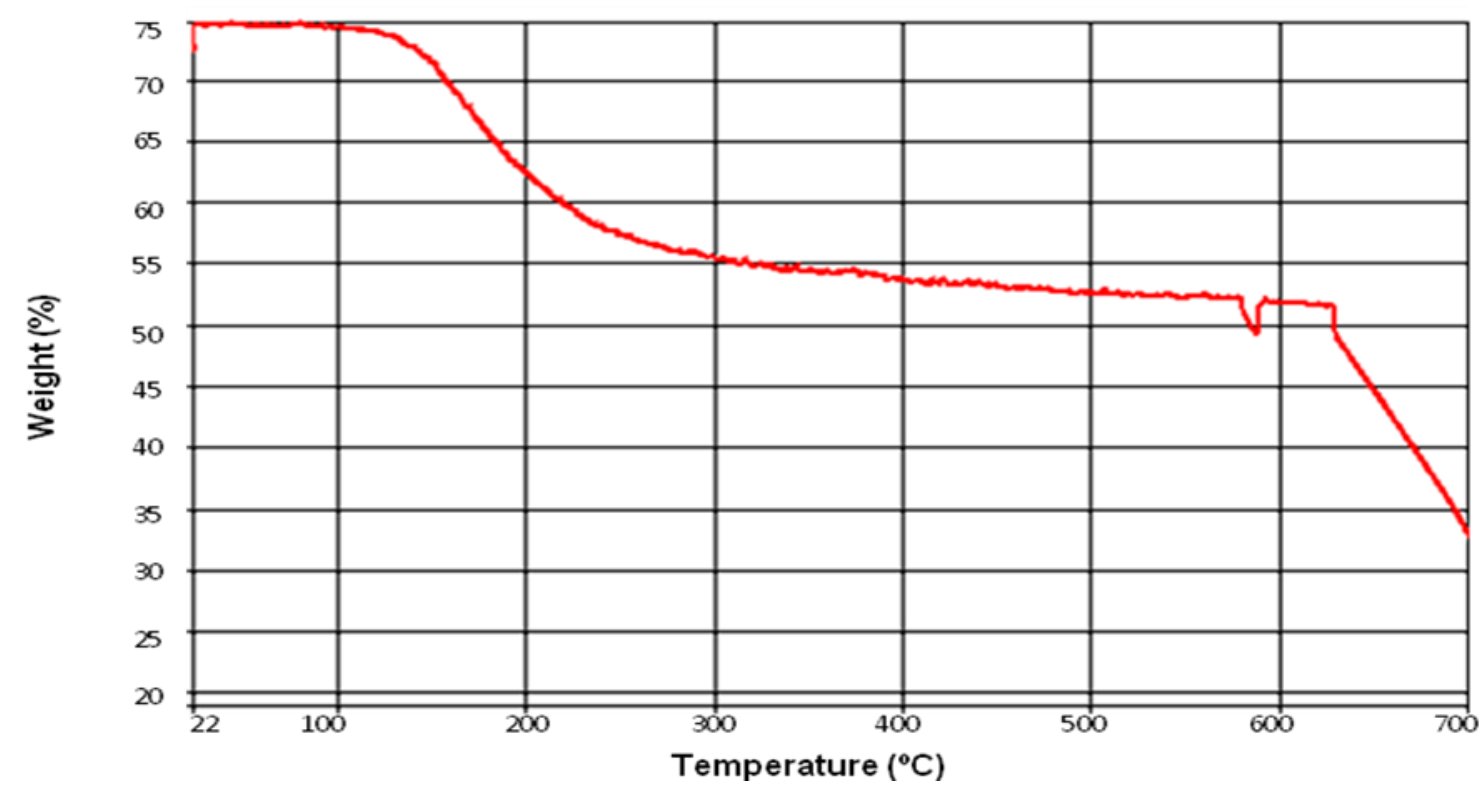

Figure 7. Thermogravimetric analysis of purified polysaccharide bioflocculant from Virgibacillus sp. Rob

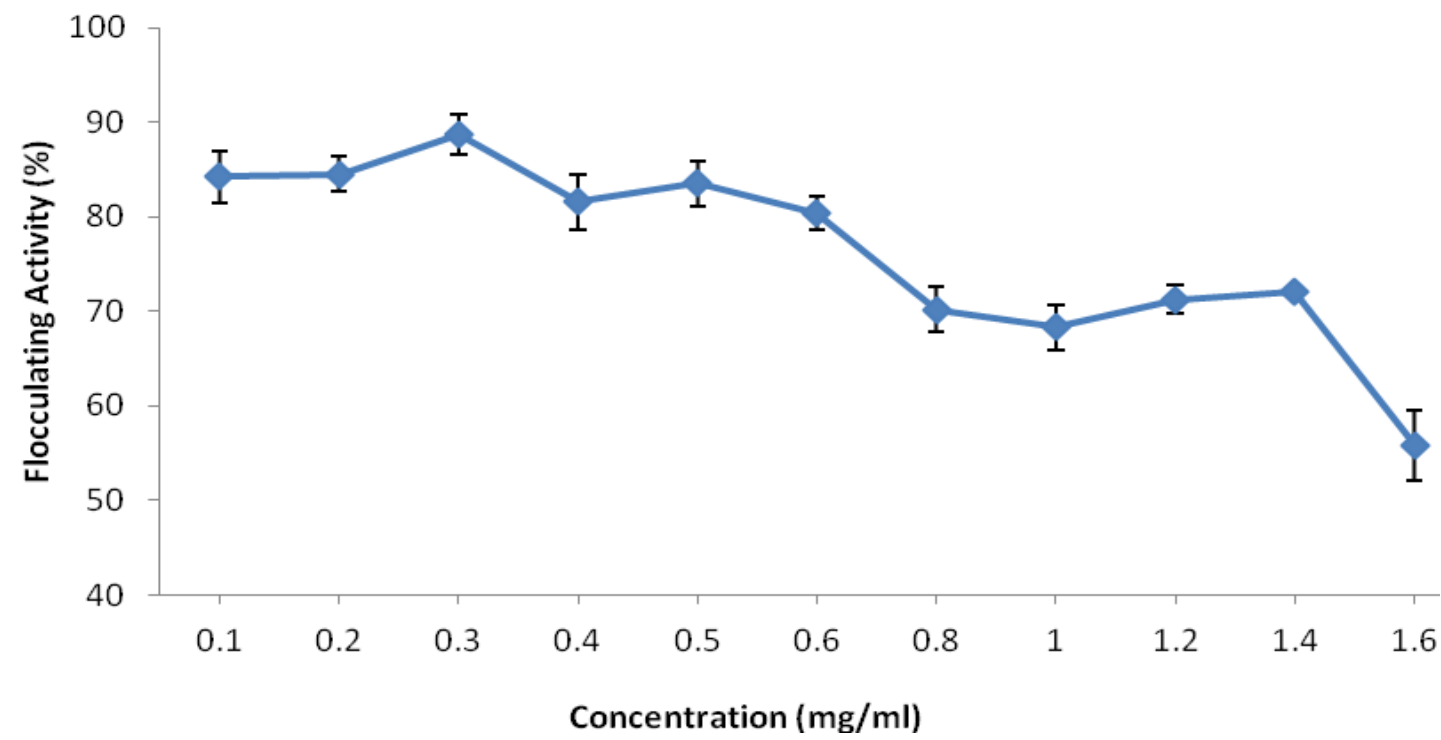

Figure 8. Effect of bioflocculant concentration on flocculation. Error bars represent the standard deviation of mean value of

stability of the bioflocculant as reported overleaf (Figure 7). The observed initial weight loss was due to moisture content as a result of the levels of carboxyl groups present in the bioflocculant. Yim et al. (2007) reported degradation temperature of $230^{\circ} \mathrm{C}$ for $\mathrm{p}-\mathrm{KG} 03$ bioflocculant while Kumar et al. (2004) reported Bacillus sp. I-471 bioflocculant with $\mathrm{Td}$ of $307^{\circ} \mathrm{C}$.

Dosage is still one of the vital parameters considered when determining the optimum conditions for the performance of flocculant in the process of coagulationflocculation since an insufficient dosage or over-dosage may lead to reduced performance in flocculation (Hassan et al., 2009). Therefore, it becomes indispensable to establish the optimum bioflocculant dose, as this could help minimize costs and attain better performance in the treatment processes. Studying the jar-test experiment results (Figure 8), the flocculating activity increased with increase of the biofloculant concentration. The variations 


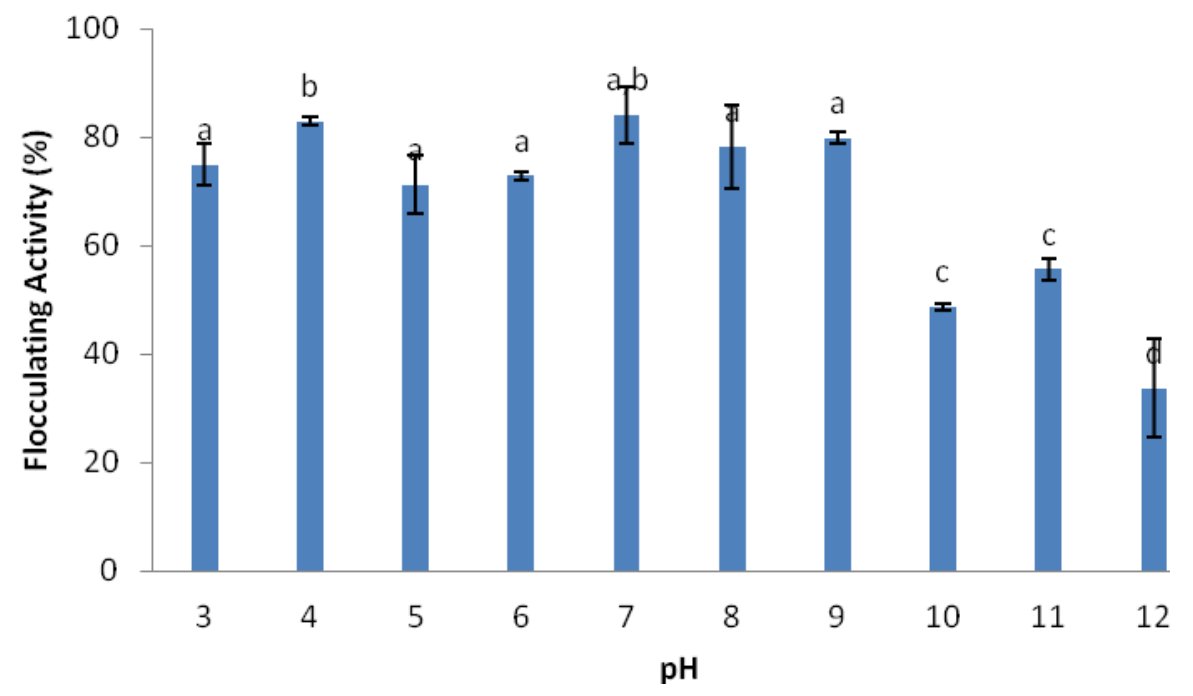

Figure 9. Effect of $\mathrm{pH}$ on flocculation. Percentage flocculating activity with different letters $(\mathrm{a}, \mathrm{b}, \mathrm{c}, \mathrm{d})$ are significantly $(p<0.05)$ different.

in flocculating activities were significantly $(p<0.05)$ different. The decrease of flocculation activity that occurred may be attributed to "flocculation deterioration" phenomenon as suggested by Liang et al. (2010) whereby some colloidal particles were enclosed up by the concentrated flocculant and a "colloid protection function" occurred, leading to reduced flocculating activity. The binding sites of the dispersive kaolin particles were blocked up by some bioflocculant molecules at high bioflocculant concentration instead of the formation of stronger bridging among the bioflocculant molecules and disperse particles in a proper flocculant concentration $(\mathrm{He}$ et al., 2010).

Literature stipulates that the alteration of $\mathrm{pH}$ may ultimately alter the bioflocculant charge status and surface characteristics of suspended materials consequently changing the flocculating ability (Zhang et al., 1999). In the present study, the flocculating activity was retained all through the $\mathrm{pH}$ range (3-12). However, the less flocculating activity at very alkaline conditions $(\mathrm{pH}$ 10-12)) (Figure 9) suggest that the alkaline degradation of the polysaccharide bioflocculant which could have resulted in a number of changes i.e. molecular rearrangements of its residue or polysaccharide chain fragmentation (Bathe and Patil, 2010). Also the mechanisms of $\mathrm{pH}$ influence on bioflocculation are still not quite apparent (Ma et al., 2008). However, it has been demonstrated that at very high $\mathrm{pH}$ the $\mathrm{OH}^{-}$ions may impede the formed complex of the bioflocculant and kaolin particles in the mixture whilst at lower $\mathrm{pH}$ the bioflocculant and the kaolin may probably adsorb the $\mathrm{H}^{+}$ leading to reduced flocculation activity. On the other hand, at neutral $\mathrm{pH}$ this mediating effect may be stronger (Li et al., 2007). A similar case was reported by He et al.
(2010) whereby the flocculating activity of a bioflocculant produced by deep sea bacteria mutant Halomonas sp. V3a' peaked at neutral $\mathrm{pH}$.

Lu et al. (2005) reported that cations have significant effect on flocculation. Mostly, the cation is used as coagulant aid in achieving high flocculation activity by neutralizing the negatively charged functional groups on the bioflocculant and suspended particles thereby increasing the adsorption of bioflocculant to the suspended particles ( $\mathrm{He}$ et al., 2010; Mabinya et al., 2011). Monovalent cations $\left(\mathrm{Na}^{+}, \mathrm{Li}^{+}\right.$and $\left.\mathrm{K}^{+}\right)$, trivalent $\mathrm{Fe}^{3+}$ had very little or no effect on flocculation activity (Figure 10). On the other hand, divalent $\left(\mathrm{Ca}^{2+}, \mathrm{Mn}^{2+}\right.$ and $\left.\mathrm{Mg}^{2+}\right)$ and trivalent $\left(\mathrm{Al}^{3+}\right)$ enhanced flocculation. However $\mathrm{Ca}^{2+}$ and $\mathrm{Al}^{3+}$ greatly enhanced flocculation. The $\mathrm{Ca}^{2+}$ ion are assumed to have enhanced the process of flocculation by neutralization and stabilization of residual negative charges of carboxyl groups of uronic acid present in the acidic polysaccharide, thereby bridges between kaolin particles and to each other were formed (Suryani et al., 2011). A similar results was observed with Gong et al. (2008) and also $\mathrm{Ca}^{2+}$ was found to significantly improve flocculation. He et al. (2010) also reported $\mathrm{Ca}^{2+}$ as cation source enhancing flocculation by bioflocculant HBF-3 produced by Halomonas sp. V3a'.

The effectiveness of our test bioflocculant was compared with those of some conventional synthetic flocculants (polyacrilamide (PAM), polyethylimine, alum, and ferric chloride) at a concentration range of 0.1-1 $\mathrm{mg} / \mathrm{ml}$ and neutral $\mathrm{pH}$ for flocculating kaolin suspension under similar conditions. The results are shown in Table 3. The bioflocculant was more efficient than the inorganic ferric chloride and alum, as well as polyethylimine, though less efficient than polyacrylamide. These findings 


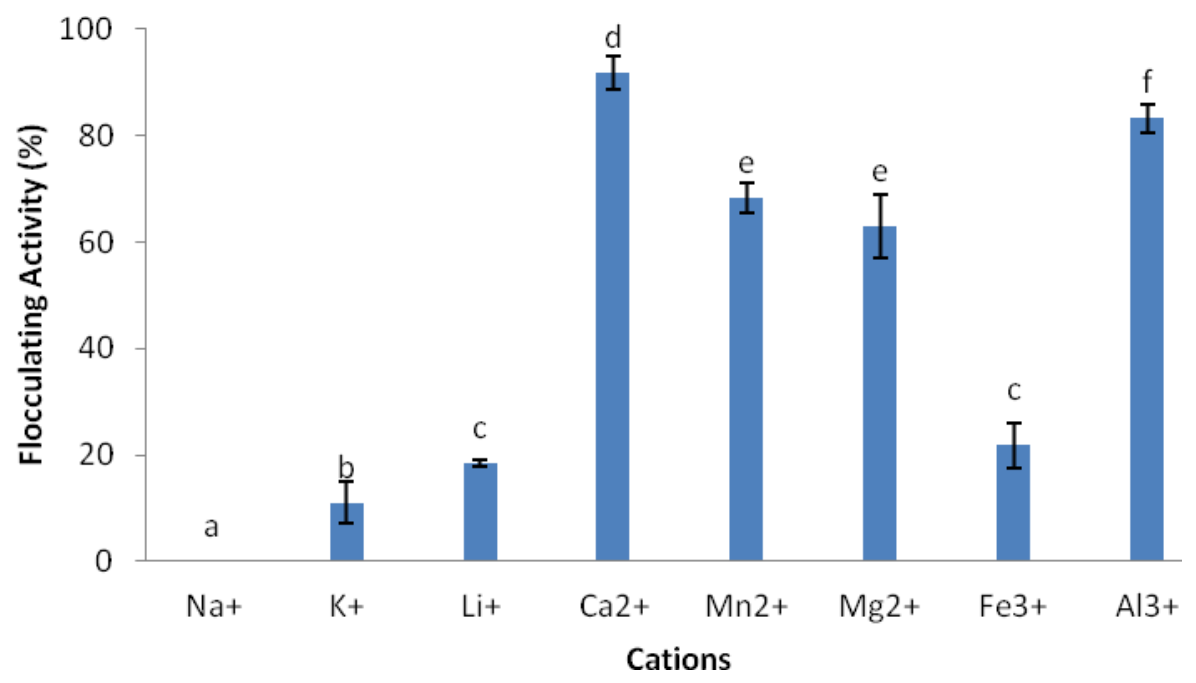

Figure 10. Effect of cations on flocculation activity. Percentage flocculating activity with different letters $(\mathrm{a}, \mathrm{b}, \mathrm{c}, \mathrm{d}, \mathrm{e}, \mathrm{f})$ are significantly $(p<0.05)$ different.

suggested that the bioflocculant could conveniently stand as alternatives to many inorganic and synthetic flocculants and facilitate their possible application in water and wastewater treatment.

\section{Conclusions}

This study corroborates our previous report and confirms that Virgibacillus $\mathrm{sp}$. Rob produces a polysaccharide bioflocculant composed mainly of uronic acids. The low optimum dose of $0.3 \mathrm{mg} / \mathrm{ml}$ of the purified bioflocculant for the flocculation of kaolin clay; the neutral $\mathrm{pH}$ required for optimal activity; and the thermal stability of the bioflocculant are significant and makes it attractive as alternative to synthetic flocculants. Its applicability in the treatment of various types of wastewater is a subject on intensive investigation in our group.

\section{ACKNOWLEDGEMENTS}

This study was financed by a grant from National Research Foundation (NRF) of South Africa.

\section{REFERENCES}

Bathe GA, Patil DM (2010). Studies on characterization of bioflocculant exopolysaccharide of Azotobacter indicus and its potential for wastewater treatment. Appl. Biochem. Biotechnol. DIO 10.1007/s12010-010-9054-5.

Bolto B, Gregory J (2007). Organic polyelectrolytes in water treatment. Water Res. 41:2301-2324.

Cesaretti M, Luppi E, Maccari F, Volpi N (2003). A 96-well assay for uronic acid carbazole reaction. Carbohydr. Polym. 54:59-61.
Chang WC, Soon AY, In HO, Sang HP (1998). Characterization of an extracellular flocculating substance produced by a planktonic

cyanobacterium, Anabaena sp. Biotechnol. Lett. 20:643-646.

Chen H, Zhang JF, Jiang PJ, Yang SL, Liu ZL (2002). Composition and characterization of microbiological flocculant SC06. Environ. Chem. 21:360-364

Chen W, Zhao Z, Chen SF, Li YQ (2008). Optimization for the production of exopolysaccharide from Fomes fomentarius in submerged culture and its antitumor effect in vitro. Bioresour. Technol. 99:3187-3194

Cosa S, Mabinya LV, Olaniran AO, Okoh OO, Okoh Al (2011). Bioflocculant production by Virgibacillus $\mathrm{sp}$. Rob isolated from the bottom sediment of Algoa Bay in the Eastern Cape, South Africa. Molecules. 16:2431-2442

Cosa S, Mabinya LV, Olaniran AO, Okoh Al (2012). Production and characterization of bioflocculant produced by Halobacillus sp. Mvuyo isolated from bottom sediment of Algoa Bay. Environ. Technol. iFirst: pp.1-7.

Dubois M, Gilles K, Hamilton JK, Rebers PA, Smith F (1956). Colorimetric method for determination of sugars and related substances. Anal. Chem. 28:350-356.

Feng LF, Xu SH (2008). Characterization of bioflocculant MBF3-3 produced by an isolated Bacillus sp. World J. Microbiol. Biotechnol. 24:1627-1632.

Gandhi HP, Ray RM, Patel RM (1998). Exopolymer production by Bacillus species. Carbohydr. Polym. 34:323-327.

Gancel F, Novel G (1994). Exopolysaccharide production by Streptococcus salivarius ssp. thermophilus cultures. 1. Conditions of production. J. Dairy Sci. 77:685-688.

Gao J, Bao H, Xin M, Liu Y, Li Q, Zhang Y (2006). Characterization of a bioflocculant from a newly isolated Vagococcus sp. W31. J. Zhejiang University Sci. B. 7:186-192.

Gong X, Wang S, Luan Z, Jia Z (2003). Screening and optimization of a bioflocculant-producing bacterium and its application in water treatment. Chin. J. Appl. Environ. Biol. 9:196-199.

Gong W, Wang S, Sun X, Liu X, Yue QY, Gao BY (2008). Bioflocculant production by culture of Serratia ficaria and its application in wastewater treatment. Bioresour. Technol. 99:4668-4674.

Ghosh M, Ganguli A, Pathak S (2009). Application of a novel biopolymer of Salmonella from poultry wastewater. Environ. Technol. 30:337-344.

Hassan MAA, Li TP, Noor ZZ (2009). Coagulation and flocculation 
treatment of wastewater in textile industry using chitosan. J. Chem. Nat. Res. Eng. 4:43-53.

He J, Zou J, Shao Z, Zhang J (2010). Characteristics and flocculating mechanism of a novel bioflocculant HBF-3 produced by deep-sea bacterium mutant Halomona sp. V3a. World J. Microbiol. Biotechnol. 26:1135-1141.

Hwang HJ, Kim SW, Choi JW, Yun JW (2003). Production and characterization of exopolysaccharides from submerged culture of Phellinus linteus KCTC 6190. Enzyme Microbiol. Technol. 33:309319.

Jamil N, Ahmed N (2008). Production of Biopolymers by Pseudomonas aeruginosa isolated from marine source. Brazilian Arch. Biol. Technol. 51:457-464.

Koizumi JI, Tskeda M, Kurane R, Nakamura J (1991). Synergetic flocculation of the bioflocculant FIX extracellularly produced by Nocardia amarae. J. Gen. Appl. Microbiol. 37:447-454.

Kumar CG, Joo HS, Kavali R, Choi JW, Chang CS (2004). Characterization of an extracellular biopolymer flocculant from a haloakalophilic Bacillus isolate. J. Microbiol. Biotechnol. 20:837-843

Kunmani P, Kumar S, Yuvaraj KA, Paari V, Arul V (2011) Production and purification of a novel exopolysaccharide from lactic acid bacterium Streptococcus phocae $\mathrm{PI} 80$ and its functional characteristics activity in vitro. Bioresour. Technol. 102:4827-4833.

Kurane R, Mutsuyama H (1994). Production of a bioflocculant by mixed culture. Biosci. Biotechnol. Biochem. 58:1589-1594.

Kurane R, Hatamochi K, Kiyohara T, Hirao M, Taniguchi Y (1994). Production of a bioflocculant by Rhodococcus erythropolis S-1 grown on alcohols. Biosci. Biotechnol. Biochem. 58:428-429.

Lee SH, Lee SO, Jang KL, Lee TH (1995). Microbial flocculant from Arcuadendron sp. TS-49. Biotechnol. Lett. 17:95-100.

Lee SH, Shin WS, Shin MC, Choi SJ, Park LS (2001). Improvement of water treatment performance by using polyamine flocculants. Environ. Technol. 22:653-659.

Li XM, Haung QY, Zeng GM, Liao X, Liu JJ, Long WF (2007). Screening and characterization of a bioflocculant produced by Aeromonas sp. Biomed. Environ. Sci. 20:274-278.

Li Z, Zhong S, Lei H, Chen R, Yu Q, Li H (2009). Production of a novel bioflocculant by Bacillus licheniformis $\mathrm{X} 14$ and its application to low temperature drinking water treatment. Bioresour.Technol.100:36503656.

Lian B, Chen Y, Zhao J, Teng H, Zhu L, Yuan S (2008). Microbial flocculation by Bacillus mucilaginosus: Applications and mechanisms. Bioresour. Technol. 99:4825-4831.

Liang Z, Han B, Liu H (2010). Optimum conditions to treat highconcentration microplate slime water with bioflocculants. Mining Sci. Technol. 20:0478-0484.

Lowry OH, Rosebrough NJ, Farr AL, Randall RJ (1951). Protein measurement with the Folin Phenol reagent. J. Biol. Chem. 193:265275.

Lu W, Zhang T, Zhang D, Li C, Wen J, Du L (2005). A novel bioflocculant produced by Enterobacter aerogenes and its use in defecating the trona suspension. Biochem. Eng. J. 27:1-7.

Ma F, Zheng LN, Chi Y (2008). Applications of biological flocculants (BFs) for coagulation treatment in water purification: Turbidity elimination. Chem. Biochem. Eng. Q. 22:321-326.

Mabinya LV, Cosa S, Mkhwetshana N, Okoh Al (2011). Halomonas sp. $\mathrm{OKOH}-\mathrm{a}$ marine bacterium isolated from the bottom sediment of Algoa Bay-produces a polysaccharide bioflocculant: partial characterization and biochemical analysis of its properties. Molecules. 16:4358-4370.

Piyo N, Cosa S, Mabinya LV, Okoh Al (2011). Assessment of bioflocculant production by Bacillus sp. Gilbert, a marine bacterium isolated from the bottom sediment of Algoa Bay. Mar. Drugs. 9:12321242.

Prasertsan P, Derlim W, Doelle H, Kennedy JF (2006). Screening, characterization and flocculating property of carbohydrate polymer from newly isolated Enterobacter cloacae WD7. Carbohyd. Polym. 66:289-297.

Salehizadeh H, Shojaosadati SA (2001). Extracellular biopolymeric flocculants-recent trends and biotechnological importance. Biotechnol. Adv. 19:371-385.

Sharma BR, Dhuldhoya NC, Merchant UC (2006). Flocculants Ecofriendly approach. J. Polym. Environ. 14:195-202.

Shih IL, Van YT, Yeh LC, Lin HG, Chang YN (2001). Production of a biopolymer flocculant from Bacillus licheniformis and its flocculation properties. Bioresour. Technol. 78:267-272.

Subramanian BS, Yan S, Tyagi RD, Surampalli RY (2010). Characterization of extracellular polymeric substances (EPS) extracted from both sludge and pure bacterial strains isolated from wastewater sludge for sludge dewatering. Water Res. 44:2253-2266.

Suh H, Kwon H, Lee CH, Kim HS, Oh HM, Yoon BD (1998). Characterization of bioflocculant produced by Bacillus sp. DP-152. J Ferment. Bioengineer. 84:108-112.

Suryani LA, Artika IM, Susanti HE (2011). Characterization of Bioflocculant Producing-Bacteria Isolated from Tapioca Waste Water. HAYATI J. Biosci. 18:193-196.

Takeda M, Kurane R (1991). A protein bioflocculant produced by Rhodococcus erythropolis. Agric. Biol. Chem. 55:2663-2664.

Wang Z, Wang KX, Xie YM, Yao YL (1995). Bioflocculant -producing microorganisms. Acta Microbiol. Sin. 35:121-129.

Wang L, Ma F, Qu Y, Sun D, Li A, Guo J, Yu B (2011). Characterization of a compound bioflocculant produced by mixed culture of Rhizobium radiobacter F2 and Bacillus sphaeicus F6. World J. Microbiol. Biotechnol. DOI 10.1007/s11274-011-0726-2.

Wang S, Gong W, Liu X, Tian L, Yue Q, Gao B (2007). Production of a novel bioflocculant by culture of Klebsiella mobilis using dairy wastewater. Biochem. Eng. J. 36:81-86.

Xia S, Zhang Z, Wang X, Yang A, Chen L, Zhao J, Leonard D, JaffrezicRenault N (2008). Production and characterization of bioflocculant by Proteus mirabilis TJ-1. Bioresour. Technol. 99:6520-6527.

Xiong Y, Wang Y, Yu Y, Li Q, Wang H, Chen R, He N (2010). Production and characterization of a novel bioflocculant from Bacillus licheniformis. Appl. Environ. Microbiol. 76:2778-2782.

Yim JH, Kim SJ, Ahn SH, Lee HK (2007). Characterization of novel bioflocculant, p-KG03, from a marine dinoflagellate, Gyrodium impudicum KG03. Bioresour. Technol. 98:361-367.

Zhang H, Lin Z (1999) Microbial flocculant and its application in environmental protection. J. Environ. Sci. 11:1-12.

Zhang J, Liu Z, Wang S, Jiang P (2002). Characterization of a bioflocculant produced by the marine myxobacterium Nannocystis $\mathrm{sp}$. NU2. Appl. Microbiol. Biotechnol. 59:517-522.

Zhang Z, Lin B, Xia S, Wang X, Yang A (2007). Production and application of a novel bioflocculant by multiple-microorganism consortia using brewery wastewater as carbon source. J. Environ. Sci. 19:667-673.

Zhang C, Cui Y, Wang Y (2012). Bioflocculant produced from bacteria for decolorization, $\mathrm{Cr}$ removal and swine wastewater application. Sustain. Environ. Res. 22:129-134.

Zheng Y, Ye ZL, Fang XL, Li YH, Cai WM (2008). Production and characteristics of a bioflocculant produced by Bacillus sp. F19. Biol. 99:7686-7691.

Zhu C, Chen C, Zhao L, Zhang Y, Yang J, Song L, Yang S (2011). Bioflocculant produced by Chlamydomonas reinhardtii. J. Appl. Phycol. DOI 10.1007/s10811-011-9769-x.

Zulkeflee Z, Aris AZ, Shamsuddin ZH, Yusoff MK (2012). Cation dependence, $\mathrm{pH}$ tolerance, and dosage requirement of a bioflocculant produced by Bacillus spp. UPMB13: Flocculation performance optimization through kaolin assays. Sci. World J. doi:10.1100/2012/495659. 